\title{
PENGARUH PROSES PENGERINGAN RIMPANG TEMULAWAK (Curcuma xanthorriza ROXB) TERHADAP KANDUNGAN DAN KOMPOSISI KURKUMINOID
}

\author{
Bambang Cahyono $^{1 *}$, Muhammad Diah Khoirul Huda ${ }^{1)}$, dan Leenawaty Limantara ${ }^{2)}$ \\ ${ }^{1)}$ Laboratorium Kimia Organik, Jurusan Kimia, Fakultas MIPA, Universitas Diponegoro \\ Jl. Prof. Soedharto, SH, Semarang 50275, Telp. (024)76480824 \\ ${ }^{2)}$ Ma Chung Research Center for Photosynthetic Pigments \\ Universitas Ma Chung, Malang, 65151 \\ ${ }^{*}$ Penulis korespondensi: bambang_cahyono@undip.ac.id
}

\begin{abstract}
EFFECT OF DRYING PROCESSES ON CURCUMINOID CONTENT AND COMPOSITION OF TEMULAWAK (Curcuma xanthorriza ROXB) RHIZOMES. Curcuminoid a yellow coloring agent of turmeric is known to have many benefits in food and medicinal industries. This compound can be isolated by simple extraction from fresh rhizome or symplicia. The research of comparing qualitative and quantitative of curcuminoid in different drying process has not yet been published. Drying methods used in this research were done in an oven at $60^{\circ} \mathrm{C}$ and under 30-watt electrical lamp at $\pm 30^{\circ} \mathrm{C}$. Each method was carried out in time variation of 1, 3, and 5 days. Extraction of curcuminoid was done using ethanol 95\% followed by fat reduction process using petroleum ether. Curcuminoid analysis was done by TLC, UV-Visible spectrophotometer and HPLC. The result showed that the water content of all samples was approximately $4.06 \%-7.76 \%$. TLC analysis identified the presence of two dominant components in the curcuminoid with the $R_{f}$ values of 0.37 and 0.15 . The UV-Visible spectra indicated that simplicia would give more result in curcuminoid than fresh rhizome. There were 4 substances detected in HPLC analysis, they were curcumin 61-67\%, demetoxycurcumin 22-26\%, bisdemetoxycurcumin 1-3\%, and curcuminoid derivative 10-11\%. In addition, drying on oven resulted brighter and crispier simplicia than drying under lamp.
\end{abstract}

Keywords: curcuma xanthoriza Roxb; curcuminoid; drying; turmeric

\begin{abstract}
Abstrak
Kurkuminoid yang merupakan zat utama yang berwarna kuning dalam temulawak telah diketahui memiliki banyak manfaat di bidang kesehatan dan makanan. Bahan ini dapat diisolasi dari bahan segar atau simplisia kering melalui ekstraksi. Riset yang mencoba membandingkan kualitas dan kuantitas kurkuminoid akibat perlakuan panas pada saat pembuatan simplisia hingga sekarang belum pernah dilakukan. Penelitian dimulai dengan pengeringan temulawak segar setelah dirajang pada oven suhu $60^{\circ} \mathrm{C}$ dan pada pengeringan lampu listrik 30 watt pada suhu $\pm 30^{\circ} \mathrm{C}$. Masing-masing metode dilakukan variasi lama pengeringan 1, 3, 5 hari. Ekstraksi kurkuminoid dilakukan menggunakan etanol 95\% dan defatisasi menggunakan petroleum eter, sedangkan analisis kualtatif dan kuantitatif kurkuminoid direalisasikan dengan KLT, spektrofotometer UV-Tampak dan KCKT. Hasil penelitian menunjukkan bahwa kandungan air semua sampel sekitar 4,06\%-7,76\%. Analisis $K L T$ mengidentifikasi adanya dua komponen dominan dalam kurkuminoid dengan nilai $R_{f} 0,37$ dan 0,15. Hasil analisis Spektrofotometri UV-tampak memberikan keenderungan bahwa kurkuminoid dari sampel kering lebih mudah terekstraksi daripada sampel basah. Kromatogram HPLC dapat mendeteksi adanya 4 senyawa yaitu kurkumin 61-67\%, demetoksikurkumin 22-26\%, bisdemetoksikurkumin 1-3\%, dan turunan kurkuminoid 10-11\%, urutan prosentase masing-masing komponen tetap sama selama proses pengeringan. Hasil penelitian ini juga telah dapat menunjukkan bahwa perbedaan kondisi operasi pengeringan sangat mempenaruhi penampakan simplisia yang dihasilkan, pengeringan oven memiliki warna lebih cerah dan lebih meremah daripada pengeringan lampu.
\end{abstract}

Kata kunci: curcuma xanthoriza Roxb; kurkuminoid; pengeringan; temulawak 


\section{PENDAHULUAN}

Permintaan pasar terhadap bahan baku obat bahan alam akhir-akhir ini terus menunjukkan peningkatan yang sangat berarti. Hal ini diduga karena adanya trend baru di masyarakat untuk menggunakan bahan alam sebagai pengganti bahan-bahan sintetik. Salah satu komoditas bahan alam andalan Indonesia, yakni temulawak (Curcuma Xanthoriza ROXB), merupakan bahan yang sangat strategis untuk dikembangkan mengingat banyaknya manfaat yang ditunjukkan oleh bahan aktif kurkuminoid. Telah dilaporkan bahwa bahan alam ini dikonsumsi dalam bentuk campuran senyawa diarilheptanoid, yakni kurkumin (1), demetoksi kurkumin (2), dan bisdemetoksikurkumin (3).<smiles>[R12]O[C@H]1C=C(/C=C/c2ccc(O)c([R1])c2)ONO1</smiles>

Zat warna kuning alami yang diperbolehkan untuk pewarna makanan ini telah cukup lama dikenal sebagai obat batuk, obat gangguan hati, rematik, dan sinusitis (review: Jayaprakasha, 2005). Keberadaan gugusan phenolik pada ketiga senyawa tersebut dilaporkan juga menyebabkan aktivitas antioksidan yang kuat pada system biologis (Ahsan, 1998), sehingga dapat mencegah penyakit-penyakit yang berhubungan dengan reaksi peroksidasi. Bahkan, Institut Nasional Kanker telah mencoba mengembangkan bahan ini dalam uji klinis anti kanker (Kelloff, 2000), dan penelitian-penelitian praklinis lain terus dilakukan terhadap sel kanker yang lain (Iqbal, 2003).

Di Indonesia, bahan baku kurkumnoid dari rimpang temulawak dimanfaatkan oleh industri obat dalam bentuk segar dan/atau dalam bentuk simplisia. Penyimpanan simplisia dalam bentuk kering sangat dibutuhkan masyarakat guna mengatasi kendala over suplay pada saat musim panen. Secara tradisional, bahan ini dipoduksi melalui tahapan perajangan dengan pisau atau mesin, diikuti dengan pengeringan dibawah sinar matahari dan pengemasan. Sekelompok kecil masyarakat telah menggunakan oven sebagai alat pengering (Cahyono, 2007).

Pengamatan sepintas menunjukkan bahwa tampilan fisik dari produk simplisia oven lebih cerah dibanding dengan pengeringan sinar matahari sehingga pengeringan dengan oven lebih disarankan guna memenuhi tuntutan SNI. Bagaimanapun, penelitian sistematis yang mencoba membandingkan kualitas kurkuminoid dari rimpang temulawak akibat perbedaan metode pengeringan hingga saat ini belum pernah dilaporkan.

Perbedaan tampilan fisik berupa warna dari produk simplisia yang dikeringkan dengan oven dan sinar matahari tersebut dapat dimungkinkan karena telah terjadi perubahan kualitas dan kuantitas kurkuminoid yang terkandung didalam produk simplisia. Kurkumin merupakan pigmen berwarna kuning dari serbuk kunyit (Jasim dan Ali, 1988). Kurkumin tersedia secara komersial yang terdiri atas campuran ketiga golongan kurkuminoid dimana kurkumin sebagai pigmen utamanya (Ahsan dkk., 1999). Lin dkk. (2009) menyatakan bahwa mikroemulsi yang mengandung kurkumin tetap berwarna kuning transparan selama kurang lebih 14 hari pada suhu $37^{\circ} \mathrm{C}$. Namun kurkumin mengalami degradasi dibawah kondisi asam, basa, pengoksidasian, dan pencahayaan. Kurkumin mengalami degradasi setelah diekspose dengan cahaya UV dan daylight, hal ini dapat dilihat dari hasil pengamatan dengan kromatografi lapis tipis kinerja tinggi yang ditunjukkan telah terbentuk 3 dan 5 totol warna untuk setiap perlakuannya, secara berturut-turut (Ansari dkk., 2005). Kurkumin mengalami fotodegradasi ketika dipaparkan terhadap cahaya didalam larutan seperti dalam bentuk padatan (Tonnesen dkk., 1985). Perlakuan pemanasan berupa pendidihan serbuk kunyit selama 20 menit menyebabkan kandungan kurkumin mengalami penurunan sebesar 32\% (Suresh dkk., 2007).

Penelitian dimulai dengan penyiapan pembuatan simplisia melalui perajangan, diikuti dengan analisis efektivitas waktu yang diperlukan untuk pembuatan simplisia dengan oven $\left(60^{\circ} \mathrm{C}\right)$ dan pengeringan lampu $\left(30^{\circ} \mathrm{C}\right)$ yang dapat mewakili proses pengeringan dengan sinar matahari. Pemeriksaan dilanjutkan dengan penentuan kadar kurkumnoid total dari masing-masing produk dengan spektrofotometri, yang kemudian diakhiri dengan analisis komposisi kurkuminoid akibat perbedaan pengeringan, melalui Kromaografi cair kinerja tinggi (KCKT, High Performace Liquid Chromatography, HPLC). Hasil dari penelitian ini diharapkan dapat memberi informasi kepada masyarakat luas mengenai arti penting pemilihan metode pasca panen dan selanjutnya dapat dijadikan dasar Pemerintah (Daerah) guna pengambilan kebijakan pengembangan pertanian pada tanaman obat.

\section{METODE PENELITIAN Bahan}

Bahan yang digunakan dalam penelitian ini adalah rimpang temulawak segar yang diperoleh dari Pasar Jati Banyumanik Semarang, yang telah disortir ukurannya, etanol 95\%, akuabides, dan bahan kimia lain berkualitas P.A., kecuali bila disebutkan lain.

\section{Alat}

Peralatan yang digunakan dalam penelitian ini adalah alat perajang rimpang temulawak, oven listrik 
digital Hellmet, oven lampu listrik 30 watt sehingga temperature ruang $30^{\circ} \mathrm{C}$, spektrofotometer UVTampak berkas rangkap Varian Cary 50, HPLC Shimadzu LC-20AB dengan spesifikasi kolom fase terbalik, $\mathrm{C}_{18}, 5 \mu \mathrm{m}$, diameter $4 \mathrm{~mm}$ x $25 \mathrm{~mm}$.

\section{Cara Kerja \\ Preparasi rimpang temulawak}

Rimpang temulawak segar dicuci dengan air bersih. Kemudian ditiriskan dan dirajang kecil-kecil. Kemudian dari sampel yang telah dirajang, ditimbang seberat 3 g sebanyak 35 ulangan.

\section{Pengeringan sampel temulawak}

Rimpang temulawak dikeringkan melalui 2 cara, yaitu: pengeringan menggunakan oven pada suhu $60^{\circ} \mathrm{C}$ dan pengeringan menggunakan lampu dengan daya sebesar 30 watt (diukur suhu ruang $30^{\circ} \mathrm{C}$ ). Masing-masing Pengeringan tersebut dilakukan variasi lama pengeringan, yaitu 1 hari, 3 hari, dan 5 hari dengan masing-masing sampel sebanyak 5 kali ulangan. Sampel keseluruhan sebanyak 7 jenis, yaitu segar, pengeringan lampu L1 (lampu 1 hari), L3 (lampu 3 hari), L5 (lampu 5 hari), pengeringan oven O1 (oven 1 hari), O3 (oven 3 hari), O5 (oven 5 hari).

\section{Ekstraksi kurkuminoid}

Sampel temulawak setiap perlakuan diekstrak dengan etanol 95\% selama 45 menit dengan tiga kali ekstraksi sampai larutan tidak berwarna. Ekstrak yang diperoleh lalu disimpan selama 24 jam dalam freezer. Ekstrak kemudian dievaporasi dengan rotary vacuum evaporator pada suhu $50^{\circ} \mathrm{C}$. Setelah itu didefatisasi dengan petroleum eter, residu yang diperoleh dikeringkan dengan oven pada suhu $50^{\circ} \mathrm{C}$. Residu kering yang masih menempel pada kertas saring kemudian dilarutkan kembali dengan etanol 95\%. Ekstrak yang diperoleh dimasukkan dalam vial lalu dikeringkan dengan gas $\mathrm{N}_{2}$, dan dilarutkan kembali hingga volume menjadi tepat $10 \mathrm{ml}$ guna keperluan analisis lebih lanjut.

\section{Analisis kurkuminoid dengan Thin Layer Chromatography (TLC) \\ Pelat TLC $7 \times 7 \mathrm{~cm}$ ditandai dengan pensil batas} bawahnya kira-kira $1 \mathrm{~cm}$ dari ujung bawah sebagai tempat penotolan sampel dan batas atas kira-kira $1 \mathrm{~cm}$ dari ujung atas untuk menandai pelarut. Kemudian disiapkan pula bejana pengembang yang berisi campuran pelarut $\mathrm{CHCl}_{3}: \mathrm{Et}-\mathrm{OH}$ sebanyak $(14,7 \mathrm{ml}$ : 0,3 ml). Selanjutnya, seluruh sampel (segar, O1, O3, O5, L1, L3, L5) ditotolkan dalam satu pelat KLT. Kemudian pelat KLT dimasukkan dalam bejana pengembang yang telah disiapkan. Lalu dilakukan elusi sehingga pelarut merambat sampai tanda batas atas yang telah ditandai. Pelat diangkat, dikeringkan sebentar lalu nodanya dilihat dibawah lampu UV pada panjang gelombang $254 \mathrm{~nm}$.

\section{Analisis kurkuminoid dengan Spektrofotometer UV-Tampak}

Setiap sampel yang telah dilarutkan dalam etanol lalu dimasukkan dalam kuvet, kemudian diukur absorbansinya pada panjang gelombang $425 \mathrm{~nm}$.

\section{Analisis kurkuminoid dengan KCKT}

Sistem KCKT yang digunakan untuk analisis kurkuminoid adalah sistem KCKT dengan fasa stasioner $\mathrm{C}_{18}$ dan fasa gerak (asetonitril:asam asetat:akuabides=50:1:49). Elusi yang digunakan yaitu isokratik pada panjang gelombang $425 \mathrm{~nm}$ dengan kecepatan alir $1 \mathrm{ml} / \mathrm{menit}$.

\section{HASIL DAN PEMBAHASAN}

Penelitian mengenai pengaruh pengeringan terhadap senyawa aktif dalam rimpang temulawak (Curcuma xanthorriza ROXB) sangat diperlukan dalam rangka mengetahui kemungkinan adanya interaksi panas yang diaplikasikan terhadap senyawasenyawa organik, khususnya tiga komponen utama kurkuminoid. Perlakuan pengeringan pada penelitian ini dilakukan dengan dua cara, yaitu pengeringan menggunakan sinar lampu listrik 30 watt dengan suhu $30^{\circ} \mathrm{C}$ dan pengeringan oven pada suhu $60^{\circ} \mathrm{C}$. Pengeringan dengan sinar lampu listrik diaplikasikan sebagai alternatif pengganti sinar matahari karena sinar lampu memiliki intensitas dan suhu relatif lebih stabil dibandingkan cahaya matahari. Secara tradisional masyarakat melakukan pengeringan bahan alam dengan sinar matahari selama rentang waktu 3-5 hari. Berpijak dari hal tersebut, maka dalam penelitian ini dilakukan variasi lama pengeringan, yaitu 1 hari, 3 hari, dan 5 hari untuk masing-masing metode pengeringan, berttujuan untuk mengetahui pengaruh lama pengeringan terhadap kandungan kurkuminoid temulawak. Pada bagian pertama, pembahasan akan difokuskan pada karakteristik makroskopis kualitas temulawak kering yang diperoleh secara keseluruhan (dilihat dari kadar air yang tersisa, warna, bau, dan tekstur/keempukan), sedangkan pada bagian kedua dibahas karakteristik mikroskopis sampel dan difokuskan pada kandungan kurkuminoidnya.

\section{Kadar Air dan Uji Fisik}

Salah satu parameter utama dari kualitas simplisia temulawak adalah kadar airnya (RSNI 2006), mengingat mikroorganisme dapat tumbuh pada rimpang temulawak dengan kadar air $>10 \%$ yang akan mempengaruhi reaksi enzimatis sehingga mempercepat pembusukan. Hasil analisis kadar air dari dua metode pengeringan yang berbeda (Tabel 1) menunjukkan bahwa pengeringan dengan menggunakan oven lebih cepat dibandingkan dengan pengeringan sinar lampu.

Pengeringan dengan oven telah menunjukkan angka kadar air yang stabil dalam kurun waktu hanya 1 hari, sedangkan sinar lampu membutuhkan waktu 5 hari. 
Tabel 1. Kadar air sisa sampel temulawak hasil pengeringan

\begin{tabular}{lllllll}
\hline Sampel & O1 & O3 & O5 & L1 & L3 & L5 \\
\hline Kadar air tertinggal setelah pengeringan & $4,99 \%$ & $4,7 \%$ & $4,06 \%$ & $26,86 \%$ & $7,76 \%$ & $6,38 \%$ \\
\hline
\end{tabular}

Dilihat secara makroskopik, sampel hasil pengeringan kedua metode tersebut menghasilkan warna yang berbeda. Sampel pengeringan oven menghasilkan warna kuning orange yang lebih cerah, sedangkan sampel pengeringan lampu lebih pucat, terutama dapat dilihat pada sampel L1 yang menghasilkan warna agak berbeda, yaitu kuning kecoklatan. Pada tinjauan teksturnya, kecuali sampel L1, semua sampel yang memiliki kadar air $>10 \%$ jika diremas mudah meremah atau mudah patah. Dilihat dari faktor bau, juga terlihat adanya perbedaan. Secara keseluruhan sampel pengeringan oven mempunyai bau khas temulawak lebih menyengat daripada pengeringan lampu.

\section{Ekstraksi dan Analisis Kurkuminoid Ekstraksi}

Setelah proses pengeringan selanjutnya dilakukan proses isolasi kurkumioid dengan cara ekstraksi pelarut. Kurkuminoid diisolasi dengan pelarut etanol 95\% mengingat metode ini telah terbukti efektif untuk mengekstrak kurkuminoid (Photitirat, 2004; Jayaprakasha, 2005). Secara tampilan fisik, powder kurkuminoid yang telah terbebas lemaknya dari bahan segar dan simplisia tidak ada bedanya.

\section{Analisis Spektrofotometri UV-Tampak}

Di dalam suatu larutan, prinsip pewarnaan dari kurkuminoid adalah tampilnya bentuk tautomeri ketoenol, serta sekitar 95\% berada dalam bentuk konfigurasi enol (Gambar 2) (Bong, 1999).

Secara keseluruhan, kandungan sampel yang dikeringkan cenderung lebih besar daripada sampel segar, diduga disebabkan perlakuan pengeringan dapat meratakan penyebaran kurkuminoid dalam rimpang temulawak, sehingga akan memudahkan pelarut mengekstrak kurkuminoid. Pigmen kurkuminoid yang<smiles>[R]c1cc(/C=C/C(=O)CC(=O)/C=C/c2ccc(O)c([R2])c2)ccc1O</smiles>

terdapat dalam rimpang temulawak segar berada bersama-sama dengan minyak atsiri di dalam oleoresin dan kurkuminoid tidak merata bahkan memusat. Pemanasan rimpang segar akan memecahkan sel oleoresin dan kurkuminoid menjadi lebih merata dalam rimpang. Perbedaan kandungan kurkuminoid sampel segar dan sampel yang mengalami proses pengeringan juga ditentukan oleh kadar air sampel yang berbeda lebih tinggi pada sampel segar.

\section{Analisis KLT}

Identifikasi keberadaan kurkuminoid hasil ekstraksi dapat dilakukan secara cepat dengan KLT, menggnakan fase diam silika gel $\mathrm{GF}_{254}$ dan Fase gerak campuran $\mathrm{CHCl}_{3} / \mathrm{Et}-\mathrm{OH} \quad$ (98/2). Gambar 1 menunjukkan pola kromatogram hasil KLT. Seluruh sampel (segar, O1, O3, O5, L1, L3, L5) memperlihatkan pola kromatogram yang hampir sama, yaitu terdeteksi 2 noda berwarna kuning pada pelat KLT.

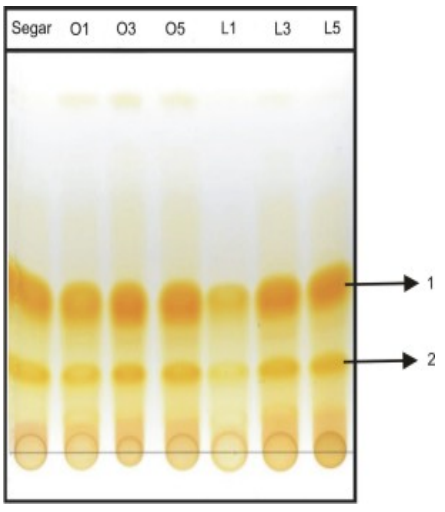

Gambar 1. Pola KLT kurkuminoid dari 7 sampel (Segar, O1, O3, O5, L1, L3, L5) dengan fase gerak $\mathrm{CHCl}_{3}$ : Et-OH (98 : 2)<smiles>[R]c1cc(/C=C/C(=O)/C=C(O)/C=C/c2ccc(O)c([R2])c2)ccc1O</smiles>
Enol

Gambar 2. Struktur keto-enol kurkuminoid

Tabel 2. Nilai kadar kurkuminoid hasil analisis dengan Spektrofotometri UV-Tampak

\begin{tabular}{llllllll}
\hline Sampel & Segar & L1 & L3 & L5 & O1 & O3 & O5 \\
\hline Kadar Kurkuminoid & $1,07 \%$ & $0,87 \%$ & $1,20 \%$ & $1,13 \%$ & $1,27 \%$ & $1,27 \%$ & $1,27 \%$ \\
\hline
\end{tabular}

Tabel 3. Komponen kurkuminoid, Harga $\mathrm{R}_{\mathrm{f}}$ dan warna senyawa hasil KLT

\begin{tabular}{lccc}
\hline \multirow{2}{*}{ Nama Senyawa } & \multicolumn{2}{c}{ Nilai $\mathrm{R}_{\mathrm{f}}$} & \multirow{2}{*}{ Warna } \\
\cline { 2 - 3 } & Standar & Sampel & \\
\hline Kurkumin (1) & 0,3 & 0,37 & Kuning pekat \\
Demetoksikurkumin (2) & 0,15 & 0,15 & Kuning \\
\hline
\end{tabular}


Dibandingkan dengan harga Rf literatur (Govindarajan, 1980), noda-noda hasil KLT dapat diusulkan sebagai senyawa kurkumin (noda 1) dan demetoksikurkumin (noda 2). Intensitas warna noda 1 lebih pekat daripada noda 2 (demetoksikurkumin), sehingga dapat memberikan indikasi awal bahwa kandungan senyawa kurkumin lebih besar daripada senyawa demetoksikurkumin. Senyawa bisdemetoksikurkumin tidak terdeteksi, diduga kadarnya relatif kecil. Oleh karena itu, untuk mengetahui komposisi kurkuminoid yang lebih terinci dilakukan analisis KCKT.

\section{Analisis KCKT}

Sistem KCKT yang digunakan dalam penelitian ini adalah KCKT dengan kolom fase terbalik (reverse phase) $\mathrm{C}_{18}$, fase gerak (asetonitril/ asam asetat/aquabides dengan perbandingan 50/1/49). Gambar 3 menunjukkan spektra komponen kurkuminoid (demetoksi-kurkumin, kurkumin, bisdemetoksi-kurkumin dan isomer kurkumin) hasil analisis dengan KCKT. Spektra ini diperoleh pada sampel segar, L5, dan O5 dan pada panjang gelombang maksimum serapan kurkuminoid, yaitu 425 nm. Spektra ini menunjukkan bahwa keempat senyawa tersebut adalah senyawa kurkuminoid.

Gambar 4 adalah kromatogram KCKT kurkuminoid sampel segar. Pada kromatogram tersebut memperlihatkan terdapat 4 senyawa yang terpisah dan terdeteksi yang ditandai dengan terlihatnya 4 puncak yang memiliki waktu tambat berbeda-beda. Dengan perbandingan pola kromatogram literatur dengan sistem elusi yang sama (Guddadarangavvanahally, 2002), puncak 1 diusulkan sebagai sebagai senyawa bisdemetoksikurkumin, puncak 2 demetoksikurkumin, puncak 3 senyawa kurkumin dan puncak 4 merupakan senyawa isomer dari kurkumin.

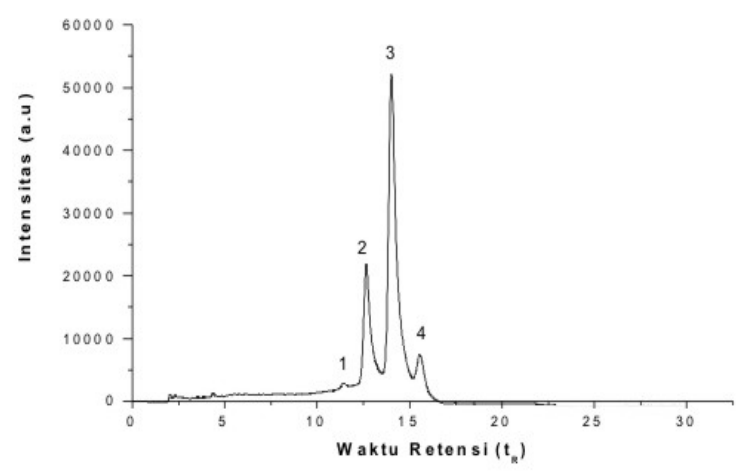

Gambar 4. Kromatogram KCKT ekstrak kurkuminoid dari sampel temulawak segar

Di dalam larutan, bentuk stabil dari kurkuminoid adalah konfigurasi trans-trans. Terbentuknya isomer cis-trans ini dimungkinkan mengingat adanya ikatan rangkap yang terdapat pada dua gugus etilen di sisi samping dari struktur lingkar benzena. Nilai waktu retensi, intensitas, dan persen area secara lengkap dapat dilihat pada Tabel 4 . Perbedaan antara kromatogram segar dan sampelsampel pengeringan terletak pada nilai intensitasnya (Srinivasan, 2005). Intensitas kurkuminoid dari yang tertinggi ke terendah berturut-turut adalah kurkumin, demetoksikurkumin, isomer kurkumin, dan bisdemetoksikurkumin. Hal ini didukung oleh penelitian Jayaprakasha dkk (2002) yang menyatakan bahwa kurkumin merupakan golongan kurkuminoid utama pada 4 jenis kunyit dan kemudian diikuti oleh demetoksikurkumin serta bisdemetoksikurkumin.

Gambar 5 memperlihatkan kromatogram komponen kurkuminoid dari sampel pengeringan L1, L3, L5, O1, O3, O5. Di dalam setiap sampel terdeteksi 4 puncak seperti halnya sampel segar dengan urutan terdeteksi yaitu bisdemetoksikurkumin, demetoksikurkumin, kurkumin, dan isomer dari kurkuminoid sehingga dapat diduga tidak adanya senyawa dari kurkuminoid yang hilang selama proses pemanasan.

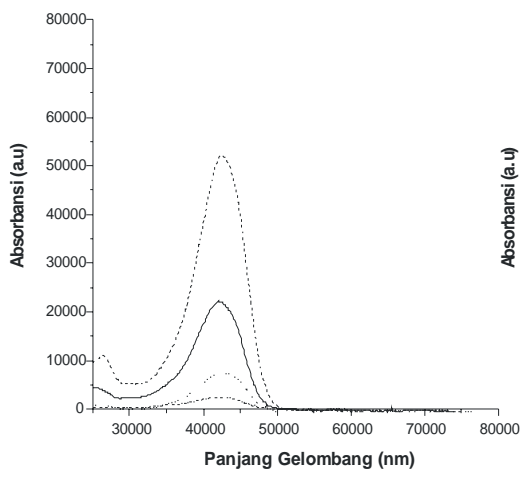

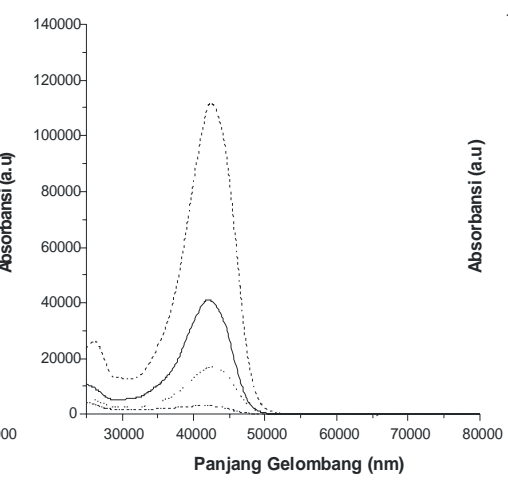

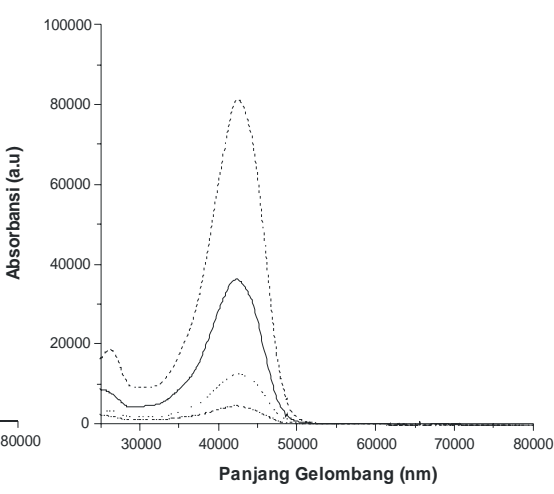

Gambar 3. Spektra kurkumin ( - - - ), demetoksikurkumin (-), dan bisdemetoksikurkumin $(\cdots)$ ) pada sampel segar (A), L5 (B), dan O5 (C) 
Tabel 4. Waktu tambat, luas, \% luas, dan rasio setiap puncak pada kromatogram KCKT ekstrak kurkuminoid dari temulawak segar dan setelah perlakuan pengeringan

\begin{tabular}{|c|c|c|c|c|c|}
\hline Sampel & Puncak & Waktu Tambat & Luas & \% Luas & Rasio \\
\hline \multirow[t]{4}{*}{ Segar } & 1 & 11,440 & 98.034 & 3,426 & \multirow{4}{*}{$3: 26: 61: 10$} \\
\hline & 2 & 12,649 & 740.977 & 25,891 & \\
\hline & 3 & 14,012 & 1.751 .476 & 61,201 & \\
\hline & 4 & 15,546 & 271.358 & 9,482 & \\
\hline \multirow[t]{4}{*}{ L1 } & 1 & 11,104 & 83.743 & 1,866 & \multirow{4}{*}{$2: 24: 64: 10$} \\
\hline & 2 & 12,366 & 1.081 .363 & 24,106 & \\
\hline & 3 & 13,767 & 2.861 .462 & 63,791 & \\
\hline & 4 & 15,296 & 459.208 & 10,237 & \\
\hline \multirow[t]{4}{*}{ L3 } & 1 & 11,257 & 34.785 & 2,111 & \multirow{4}{*}{$2: 25: 62: 11$} \\
\hline & 2 & 12,550 & 411.325 & 24,962 & \\
\hline & 3 & 13,930 & 1.028 .325 & 62,406 & \\
\hline & 4 & 15,408 & 173.357 & 10,521 & \\
\hline \multirow[t]{4}{*}{ L5 } & 1 & 11,174 & 94.489 & 2,323 & \multirow{4}{*}{$2: 26: 62: 10$} \\
\hline & 2 & 12,445 & 1.036.199 & 25,463 & \\
\hline & 3 & 13,837 & 2.534 .160 & 62,275 & \\
\hline & 4 & 15,365 & 404.475 & 9,939 & \\
\hline \multirow[t]{4}{*}{ O1 } & 1 & 11,406 & 51.098 & 1,276 & \multirow{4}{*}{ 1:22:66:11 } \\
\hline & 2 & 12,643 & 869.149 & 21,709 & \\
\hline & 3 & 14,012 & 2.658 .539 & 66,404 & \\
\hline & 4 & 15,559 & 424.794 & 10,611 & \\
\hline \multirow[t]{4}{*}{$\mathrm{O} 3$} & 1 & 11,059 & 213.601 & 2,471 & \multirow{4}{*}{$3: 25: 62: 10$} \\
\hline & 2 & 12,318 & 2.177 .718 & 25,185 & \\
\hline & 3 & 13,717 & 5.391.221 & 62,349 & \\
\hline & 4 & 15,243 & 864.284 & 9,995 & \\
\hline \multirow[t]{4}{*}{ O5 } & 1 & 11,061 & 40.953 & 0,797 & \multirow{4}{*}{$1: 22: 67: 10$} \\
\hline & 2 & 12,309 & 1.113 .383 & 21,671 & \\
\hline & 3 & 13,700 & 3.437 .049 & 66,896 & \\
\hline & 4 & 15,228 & 546.465 & 10,636 & \\
\hline
\end{tabular}
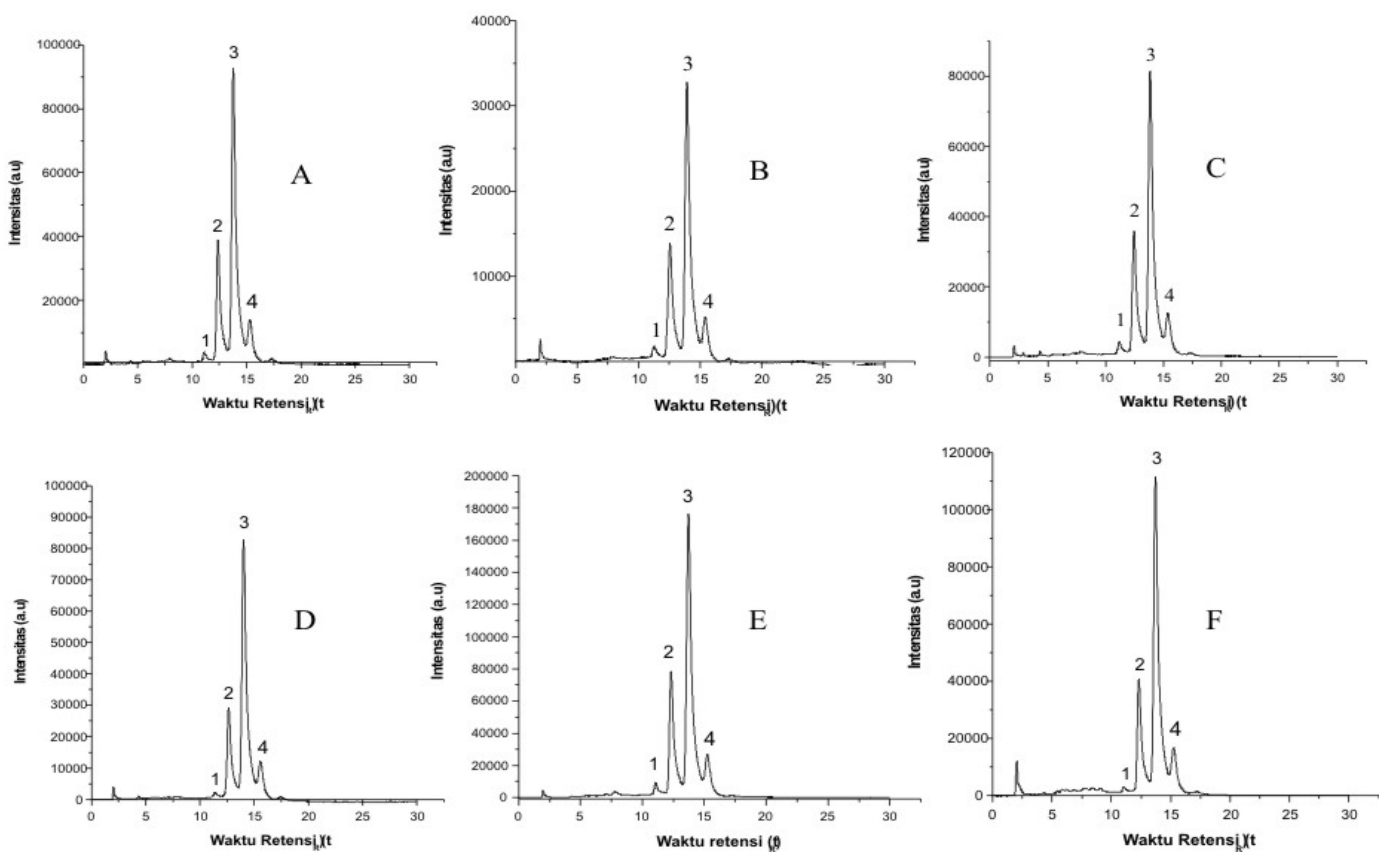

Gambar 5. Kromatogram KCKT ekstrak kurkuminod sampel temulawak yang telah mengalami proses pengeringan, A(L1), B(L3), C(L5), D(O1), E(O3), F(O5)

Tabel 4 adalah hasil rata-rata luas puncak keempat komponen kurkuminoid pada beberapa panjang gelombang spektra kurkuminoid, yaitu 300, 325, 350, 375, 400, 425, 450, dan 475. Dari tabel tersebut juga dapat dilihat rasio kandungan komponenkomponen kurkuminoid. Kurkumin merupakan komponen utama dari ekstrak dengan kandungan paling tinggi, yaitu 61-67\%, kemudian demetoksi- 
kurkumin 22-26\%, bisdemetoksi-kurkumin 1-3\%, dan isomer kurkumin 10-11\%. Urutan komposisi komponen-komponen tersebut tetap pada semua perlakuan sehingga dapat diduga bahwa metode pengeringan tidak akan mengubah struktur kimia komponen kurkuminoid yang satu ke yang lainnya.

\section{KESIMPULAN}

Telah dapat ditunjukkan dari hasil penelitian ini bahwa metode pemanasan akan berpengaruh pada waktu yang diperlukan untuk pengeringan bahan segar menjadi simplisia. Pengolahan dengan oven lebih cepat dan memberikan hasil yang lebih baik ditinjau dari segi tampilan fisik. Telah pula dapat ditunjukkan bahwa kadar total kurkuminoid yang diekstrak dari simplisia kering memiliki kuantitas lebih banyak daripada temulawak segar (dari berat segar yang sama), tetapi diduga tidak ada konversi satu komponen kurkuminoid ke komponen lain selama proses pemanasan.

\section{DAFTAR PUSTAKA}

Ahsan, H., Parveen, N., Khan, N.U., and Hadi, S.M., (1999), Pro-oxidant, anti-oxidant and cleavage activities on DNA of curcumin and its derivatives demethoxycurcumin and bisdemethoxycurcumin, Chem.-Biol. Interact., 121, pp. 161-175.

Ansari, M.J., Ahmad, S., Kohli, K., Ali, J., and Khar, R.K., (2005), Stability-indicating HPTLC determination of curcumin in bulk drug and pharmaceutical formulations, Journal of Pharmaceutical and Biomedical Analysis, 39, pp. 132138.

Bong, P.H, (2000), Spectral and Photophysical Behaviors of Curcumin and Curcuminoids, Bull. Korean Chem. Soc., 21, pp. 81-86

Cahyono, B., (2007), Standardisasi bahan baku obat alam, Seminar Nasional Penggunaan Obat Bahan Alam dalam Pelayanan Kesehatan, Semarang.

Govindarajan, V.S., (1980), Turmeric-Chemistry, Technology and Quality, Food Sci. Nutr., 12, pp. 199301.

Guddadarangavvanahally, K.J., Lingamullu R.M.J., and Kunnumpurath, S.K., (2002), Improved HPLC Method for the Determination of Curcumin, Demethoxycurcumin, and Bisdemethoxycurcumin, $J$. Agric. Food Chem., 50, pp. 3668-3672.

Iqbal, M., Sharma, S.D., Okazaki, Y., Fujisawa, M., and Okada, S., (2003), Dietary supplementation of curcumin enhances antioxidant and phase II metabolizing enzymes in ddY male mice: possible role in protection against chemical carcinogenesis and toxicity, Pharmacol. Toxicol., 92, pp. 33-38

Jasim, F. and Ali, F. (1988), A novel method for the spectrophotometric determination of curcumin and its application to curcumin spices, J. Microchem., 38, p, 106.

Jayaprakasha, G.K., Rao, L. J. M., and Sakariah, K.K., (2005), Chemistry and biological activities of C. longa, Trends in Food Science \& Technology, 16, pp. 533-548

Jayaprakasha, G.K., Rao, L. J. M., and Sakariah, K. K., (2002), Improved HPLC Method for the Determination of Curcumin, Demethoxycurcumin, and Bisdemethoxycurcumin, J. Agric. Food Chem., 50, pp. 3668-3672.

Kelloff' G. J., Crowell, J.A., Steele, V.E., Lubet, R.A., Malone, W.A., Boone, C.W., Kopelovich, L., Hawk, E.T., Lieberman, R., Lawrence, J.A., Ali, I., Viner, J.L., and Sigman, C.C., (2000), Progress in Cancer Chemoprevention Development of Died Derived Chemopreventive Agents, J. Nutrit, 130, pp. 467(s)471(s)

Lin, C.-C., Lin, H.-Y., Chen, H.-C., Yu, M.-W., and Lee, M.-H., (2009), Stability and characterisation of phospholipid-based curcumin-encapsulated microemulsions, Food Chemistry, 116, pp. 923-928

Pothitirat, W., Supabphol, R., and Dritsanapan, W., (2004), Comparison of Free Radical Scavenging Activity and Curcuminoids Content of Turmeric Extracts Using Different Methods of Extraction, Mahidol University Journal of Pharmaceutical Sciences, 31, pp. 3-4

Srinivasan, K., (2005), Spices as influencers of body metabolism: an overview of three decades of research, Food Research International, 38, pp. 77-86

Suresh, D., Manjunatha, H., and Srinivasan, K., (2007), Effect of heat processing of spices on the concentrations of their bioactive principles: Turmeric (Curcuma longa), red pepper (Capsicum annuum) and black pepper (Piper nigrum), J. Food Comp. Anal., 20, pp. 346-351.

Tonnesen, H.H. and Karlsen, J., (1985), Studies on curcumin and curcuminoids. VI. Kinetics of curcumin degradation in aqueous solution, Z. Lebensm, Unters. Forsch., 180, pp. 402-404. 